\title{
Anton Dolinar kot doktorski študent Guida Adlerja
}

\author{
Matjaž Barbo \\ Univerza v Ljubljani \\ University of Ljubljana
}

Anton Dolinar je v obdobju med obema vojnama veljal za nesporno avtoriteto na glasbenem področju. Njegovo delovanje se je širilo vse od zvestega in požrtvovalnega pionirskega urednikovanja na ljubljanskem radiu, do dirigiranja, širšega kulturnega in organizacijskega dela, publicistike ter poučevanja. In četudi gre za enega sploh prvih slovenskih muzikologov z obranjenim doktoratom pri slovitem Guidu Adlerju na Dunaju, njegovo strokovno delo doslej žal ni bilo deležno posebne pozornosti in je celo v muzikološki literaturi obravnavano pičlo ali pa je sploh prezrto. Med redkimi zapisi o njem najdemo krajšo notico ob njegovi smrti ${ }^{1}$ ter mestoma nepopolne leksikografske zapise. ${ }^{2}$ Sicer so omembe njegovega imena in delovanja doslej praviloma obrobne in sporadične, ${ }^{3}$ pogosto pa njegovega imena strokovna literatura niti ne omenja.

Ob zagovoru svoje doktorske disertacije je Dolinar rigorosnim aktom priložil tudi življenjepis, ki dokaj natančno, seveda pa predvsem iz prve

1 Edo Škulj, »Anton Dolinar (1894-1953): Ob petdesetletnici smrti«, Cerkveni glasbenik 96, 7-8 (2003): 10.

2 "Dolinar, Anton«, v Slovenski bijografski leksikon, 1. zv.: Abraham-Erberg, ur. Izidor Cankar et al. (Ljubljana: Zadružna gospodarska banka, 1925), 141; Jože Sivec, »Dolinar, Anton«, Enciklopedija Slovenije, 2. zv. Ce-Ed., ur. Marjan Javornik (Ljubljana: Mladinska knjiga, 1988), 299.

3 Prim. Edo Škulj, Letopis slovenskega glasbenega življenja v Argentini: ob 5o. obletnici vélikega izhoda (Celje: Mohorjeva družba; Celovec: Krščanska kulturna zveza; [s. 1.]: Izseljensko društvo Slovenija v svetu, 1995), 42-43; Nataša Cigoj Krstulović, Zgodovina, spomin, dediščina: Ljubljanska Glasbena matica do konca druge svetovne vojne (Ljubljana: Založba ZRC, ZRC SAZU, 2015). 
roke in zato zanesljivo predstavlja nekaj podatkov o njegovem življenju. Nekaj podobnih podatkov je mogoče povzeti tudi iz pičle literature, ki je o tem skladatelju, dirigentu, uredniku in duhovniku sicer na voljo. Da je $\mathrm{v}$ domovini spomin nanj precej obledel, je nedvomno krivo dejstvo, da je kot politični emigrant po drugi svetovni vojni odšel v Združene države Amerike in tudi tako delil usodo nekaterih vsaj delno zamolčanih in postopno pozabljenih imen slovenske povojne emigracije. Pa vendar gre za enega najbolj pomembnih ustvarjalcev radijskega programa $\mathrm{v}$ začetnih desetletjih oddajanja Radia Ljubljana ter ne nazadnje enega muzikološko najbolj široko razgledanih glasbenikov, saj je svoj študij glasbe zaključil z doktoratom pri slovitem Guidu Adlerju na Dunaju. Prav temu njegovemu študiju in Adlerjevem vplivu na Dolinarja, s tem pa posredno na razvoj slovenske muzikologije je posvečen pričujoči prispevek.

Anton Dolinar je bil rojen 13. januarja 1894 v Trati nad Škofjo Loko, kjer je končal tudi osnovno šolanje, kot pravi sam v omenjenem življenjepisu. Gimnazijo je končal leta 1913 v eni prvih generacij maturantov na škofovih zavodih v Šentvidu nad Ljubljano (ustanovljeni 1905), tedaj edini popolnoma slovenski gimnaziji pri nas. Njegov glasbeni učitelj na gimnaziji je bil Vojteh Hybašek (1873-1947), češki duhovnik, literat in glasbenik, ki je pri nas vzgojil vrsto poznejših glasbenikov. ${ }^{4}$ Hybašek je bil nedvomno močno vplival na Dolinarja in mu dal »temeljito osnovno glasbeno izobrazbo «.'

Po gimnaziji je vpisal na ljubljanski Teološki fakulteti študij teologije (1913-17) in bil 8. junija 1917 posvečen $\mathrm{v}$ duhovnika.

Škof Jeglič, ustanovitelj šentviške gimnazije ter njen skrbni in premišljeni voditelj je želel nastaviti za glasbenega učitelja dobrega glasbenika, široko razgledanega, intelektualno močnega in človeško zanesljivega, ki si ga je izbiral iz duhovniških vrst. Na voljo je imel kar nekaj kandidatov. Eden od teh je bil Ludvik Puš (1896-1989), ki se je že v semenišču izkazal kot dober

4 Hybašek je bil izvrsten učitelj, ki je dobrih trideset let, od 1906 do upokojitve leta 1937, deloval kot glasbeni učitelj na Knezoškofijski klasični gimnaziji. Poučeval je violino, klavir, orgle, harmonij, pihala in trobila. Vzgojil je vrsto zavodskih gojencev, ki so se pozneje v veliki meri posvetili glasbi ter oblikovali kar t.i. »Hybaškovo šolo«. Mednje so sodili: Anton Dolinar, Matija Tomc, Alojzij Mav, Vilko Ukmar in Venčeslav Snoj. Prim. Stanko Premrl, »Hybášek, Vojteh (1873-1947)«, v Slovenski bijografski leksikon: 3. $z v$. Hintner - Kocen, ur. Izidor Cankar et al. (Ljubljana, Zadružna gospodarska banka, 1928), 360; Matjaž Ambrožič, »Profesorski zbor«, v Sto let Zavoda sv. Stanislava, ur. France M. Dolinar (Ljubljana : Družina, 2005), 439-440; Venceslav Snoj, »Prof. V. Hybašek«, v Letno poročilo 1937/38 (Št. Vid nad Ljubljano: Zavod sv. Stanislava, 1938), 10-11. 
glasbenik, a je moral po dveh letih in pol odstopiti zaradi jetike (vendarle je pozneje doktoriral na Filozofski fakulteti in bil dejaven pri Pevski zvezi). Med bogoslovci je kot glasbenik velik ugled užival tudi Lojze Mav (1898-1977), ki pa je po novi maši stopil $\mathrm{k}$ lazaristom in zato ravno tako ni bil povsem primeren kandidat za Jegliča. Jože Klemenčič (1892-1969) je kot najstarejši nekako samoumevno pričakoval, da ga bo škof poslal na študij, vendar mu Jeglič ni preveč zaupal, kar je pozneje zanetilo pravi spor med obema.

$\mathrm{V}$ enem zadnjih pisem (3. maja 1982), ki jih je v bogati korespondenci na uredništvo Cerkvenega glasbenika naslovil Matija Tomc (1899-1986), se je le-ta med drugim obširneje razpisal o skladatelju Jožetu Klemenčiču in $\mathrm{v}$ tem kontekstu predstavil tudi okoliščine izbire kandidata za študij na Dunaju:

"Ko je Zavod $v$ Šentvidu rabil novo moč za pouk glasbe, je menda Klemenčič pričakoval, da bo šel on študirat. Izbrali pa so Dolinarja in je Klemenčič tako izpadel. [...] Nadškof Jeglič je navadno izbral nove profesorje, ki so bili prej gojenci zavoda (če je to le šlo). Drugi profesorji so tako novega profesorja že od prej poznali; bil je tudi navajen od prej na zavodski redi in disciplino. Dolinar je bil med prvimi zavodskimi maturanti in je gotovo že / zaradi tega imel prednost pred Klemenčičem, ki ga je stari profesorski zbor verjetno bolj malo poznal, bodisi po glasbeni ali tudi po človeški strani.« ${ }^{6}$

Študij muzikologije na dunajski univerzi je Dolinar vzporedno dopolnjeval s študijem praktičnih disciplin na Oddelku za cerkveno glasbo na dunajskem konservatoriju. Tako je v zimskem semestru 1921-22 vpisal tudi študij na dunajskem glasbenem konservatoriju, kjer je leta 1923 končal oddelek za cerkveno glasbo. Sam je v omenjenem življenjepisu, ki ga je predložil ob obrambi disertacije, zapisal, da je »dve leti obiskoval Oddelek ta cerkveno glasbo dunajske glasbene akademije» (»2 Jahre die Abteilung für Kirchenmusik an der Wiener Musik-Akademie besuchte«). V omenjenem življenjepisu je zapisal, da je poleg tega harmonijo, kontrapunkt in oblikoslovje dodatno privatno študiral pri Karlu Weiglu (»Harmonie, Kontrapunkt und Formenlehre studierte ich dazu noch privat bei Dr. Karl Weigl«). Karl Weigl (1881-1949) je tedaj veljal za enega najbolj cenjenih glasbenikov na Dunaju. Široko razgledan (študiral je tako na konservatoriju kot pozneje na univerzi pri Adlerju) in tudi prijateljsko povezan z najvidnejšimi glas-

6 Edo Škulj, »Tomčeva pisma«, v Tomčev zbornik, ur. Edo Škulj (Ljubljana: Družina, 1997), 193-194. 
benimi osebnostmi svojega časa (Gustav Mahler, Richard Strauss, Bruno Walter, Alexander Zemlinsky, Arnold Schönberg, Anton Webern in številni drugi) je zagotovo predstavljal tudi mlademu Dolinarju posebno privlačen zgled, nedvomno pa mu je lahko nudil več kot dragoceno mentorsko pomoč.

Središče Dolinarjevega dunajskega študija je predstavljalo obiskovanje predavanj iz muzikologije na Filozofski fakulteti dunajske univerze na oddelku slovitega Guida Adlerja. Kako visoko je Dolinar cenil dunajski muzikološki oddelek, izpričuje njegov zapis iz leta 1923 znotraj prispevka, v katerem se sicer posveča analizi tamkajšnjega glasbenega življenja:

"Za splošno razumevanje glasbe stori veliko dunajska filozofična fakulteta s svojim oddelkom: , Musikhistorisches Institut'. Izmed seminarjev na tej fakulteti je bil ta lansko leto najmočnejši." "T

Kot je razvidno iz gradiva, hranjenega $\mathrm{v}$ dunajskem Univerzitetnem arhivu, je Dolinar vpisal šest semestrov študija, vse od zimskega semestra 1921-22 do letnega semestra 1924.

V vpisnicah posameznih vpisanih študijskih semestrov (Nationale), ki so hranjene $\mathrm{v}$ univerzitetnem arhivu dunajske univerze, se je Dolinar opredeljeval kot jugoslovanski državljan (od zimskega semestra 1922-23 kot državljan SHS), rojen na Jesenicah (spet pozneje natančneje določeno: »Trata - Slowenien«). Vsakič je v vpisnicah označena slovenščina kot njegov materni jezik in rimokatoliška veroizpoved. Označil je tudi ime očeta in njegov poklic: Gregor, »posestnik (»Grundbesitzer« - v letnem semestru 1923 kratko označen kot »kmet«, »Bauer«). Dolinar je kot duhovnik glede na vpisnico ves čas študija na Dunaju stanoval na naslovu Habsburgergasse 7, Wien I, kjer je tudi še danes katoliški študentski dom (Tomažev kolegij).

Predavanja, ki jih je Dolinar izbiral in obiskoval na Dunaju, že dokaj nakazujejo krog njegovih tudi poznejših glavnih strokovnih interesov. Pri tem je seveda nekaj predavanj vzel iz ponudbe muzikološkega oddelka, nekaj pa tudi med ponujenimi predmeti drugih oddelkov Filozofske fakultete.

V prvem vpisanem semestru (zimski semester 1921-22) je Dolinar tako poslušal dvoje predavanj o glasbeni drami profesorja Roberta Lacha (18741958; Das Musikdrama Richard Wagners, 2st. in Ursprung u. Entwicklungd. musikal. Dramas, 2 uri) ter Lachovo predavanje o Psihologiji glasbenega izraza (Die Psychologie d. musikal. Ausdruckes, 1 ura). Poleg tega je obiskoval znotraj muzikološkega oddelka še predavanje o Josephu Haydnu tedaj 
docenta Wilhelma Fischerja (1886-1962), ki je bil pozneje zaradi svojega judovskega porekla deležen nacističnega preganjanja. Zunaj oddelka za muzikologijo si je izbral filozofsko pregledno predavanje profesorja Roberta Reiningerja (1969-1955) o nacionalizmu in razsvetljenski filozofiji (Nationalismus u. Aufklarungsphilosophie von Beginn der Neuzeit bis Kant, 4 ure). Že zgodaj je tako mogoče iz tega zaslutiti Dolinarjevo poznejše strokovno angažiranje na področju glasbene filozofije, estetike in ne nazadnje narodnostnih vprašanj.

Zanimivo je, da Dolinar v prvem semestru študija muzikologije ni izbral nobenega od Adlerjevih dveh razpisanih predavanj. Tedaj je Adler namreč pripravil predavanja iz »Razlage in opredelitve umetniških del« (Erklären u. Bestimmen von Kunstwerken, 2 uri) ter "Vaje na glasbenozgodovinskem institutu " (Übungen im musikhistorischen Institut, 2 uri). Prav tako se ni odločil za predavanja Maxa Dietza (Führer und Bahnbrecher der neuromantischen Tonkunst in Sinfonik, im Oratorium und in der Oper; $m$. vielen Musikbeispielen, 3 ure), Egona Wellesza (Die Entwicklung d. großen sinfonischen Form u. d. Orchesters i. 19. Jahrh., 1 ura) in W. Fischerja (Allgemeine Musikgeschichte, 4 ure; ter Die Mensuralnotation d. 15. u. 16. Jahrh., 2 uri).

Prvič je Adlerjeva predavanja izbral vletnem semestru 1922, in sicer obe predavanji, razpisani za ta semester: Vaje iz glasbene zgodovine (Übungen im musik-hist. Inst., $2 \frac{1}{2}$ ure) ter razlaga in opredelitev umetniških del (Erklären und Bestimmen von Kunstwerken, $2 \frac{1}{2} 2$ ure). Znova je izbral tudi Lacha, tokrat s predavanji o psihologiji in estetiki sodobne glasbe (Psychologie u. Ästhetik d. Musik d. Gegenwart, 2 uri), ter Fischerja z uvodom v glasbenozgodovinsko literaturo (Einführung i. d. musikgeschichtl. Literatur, 2 uri). Poleg tega je zunaj oddelka izbral tudi uvod v latinsko paleografijo (3 ure).

Pri tem je zanimivo, da se med razpisanimi predavanji Dolinar ni odločil tokrat za dve Lachovi predavanji, pa tudi ne za Dietzev pregled klasične glasbene drame, za Fischerjeva predavanja (posvečena splošni glasbeni zgodovini in menzuralni notaciji) ter za predavanja Alfreda Orla (18891967, o glasbeni liturgiki in variacijskem principu).

V zimskem semestru 1922-23 je Dolinar znova poslušal obe Adlerjevi temeljni glasbenozgodovinski predavanji (Erklären u. Bestimmen von Kunstwerken, 2 uri; Übungen im musikhistorischen Institut, 2 uri), zato pa ne Adlerjevo specialko o Beethovnu. Prvič si je izbral tudi Orla in njegova predavanja o Antonu Brucknerju (2 uri) in gregorijanskem koralu (Einführung in den gregorianischen Choral, 1 ura). Spet je poslušal tudi Fischerja, tokrat 
o zgodovini instrumentalne glasbe (Geschichte der Instrumentalmusik, 2 uri). Zanimivo je, da si je izbral tudi cikel arheoloških predavanj o Pompejih, ki jih je pripravil rojak iz Podsrede, Arnold Schober (1886-1959; Pompeji, Entwicklung eines h. r. Stadtbildes, 1 ura), čigar mati Emma, r. Kopatsch je bila glasbeno izobražena in je izhajala iz celjske meščanske družine.

Znova v tem semestru ni vpisal nobenega od Lachovih predavanj (Dramaturgie und Ästhetik des altgriechischen Musikdramas; Allgemeine musikalische Entwicklungsgeschichte; Die musik der, orientalischen Kulturvöl$k e r$ ), prav tako pa tudi ne predavanje Egona Wellesza (o dunajski baročni operi) in W. Fischerja (o menzuralni notaciji).

V letnem semestru 1923 si je Dolinar izbral spet obe Adlerjevi temeljni predavanji (Übungen im musik-hist. Inst., $2 \frac{1}{2} 2$ ure; Eklären und Bestimmen von Kunstwerken, $2 \frac{1}{2}$ ure) ter vsa Orlova predavanja (poleg nadaljevanja predavanj o Brucknerju, 2 uri; še Die Frühzeit der Mehrstimmigkeit, 1 ura in Die Meßkomposition vom 17. Jahrhundert bis zu A. Bruckner, 2 uri). Poleg tega je vpisal še predavanja avstrijskega kulturnega filozofa Karla Roretza (1881-1967) o zgodovini novoveške psihologije (Geschichte der Psychologie der Neuzeit, 1 ura).

Orlova predavanja so očitno na Dolinarja naredila močan vtis, saj se je nedvomno prav pod njihovim vtisom lotil obsežnejšega portreta Antona Brucknerja, ki ga je objavil v Cerkvenem glasbeniku leta 1924 ob stoletnici skladateljevega rojstva. ${ }^{8} \mathrm{~S}$ tem se je poklonil velikemu skladatelju, ki je bil sicer v svojem času po Dolinarjevem mnenju deležen krivice: „Vendar, kar zakrivi sodobnost, popravi poznejša zgodovina; ona možem, ki izobrazbo svojega časa dosežejo in na podlagi te stremijo po napredku, iščejo novih potov, vódeni po neki notranji sili, popravi storjeno krivico in njihovo poslanstvo docela odkrije in razjasni.« (s. 2) Sam Dolinar je sicer v članku zapisal, da je podatke o Brucknerjevem življenju črpal iz monografije Maxa Auerja (1923), pa vendar lahko upravičeno domnevamo, da so na njegovo širšo interpretacijo skladatelja vplivala tudi Orlova predavanja.

Dolinar v interpretaciji Brucknerja poudarja nasprotje med obliko in vsebino ter $s$ tem izpeljuje splošne estetske principe, ki so tudi prek njegovega pisanja zaznamovali poznejše pisanje o glasbi pri nas, sam pa jih je, kot bomo videli tudi v nadaljevanju, prevzemal tudi pri Adlerju. Značilen v tem smislu je odlomek iz omenjenega članka o Brucknerju, v katerem lahko prepoznamo tako ideje Adlerja kot pozneje nekaterih Dolinarjevih mlajših sodobnikov, med njimi S. Vurnika in V. Ukmarja: 
"Oblika sama že pripomore k temu, da pravimo: ta in ta skladba je lepa, toda ne ona sama; oblika je le okvir, posoda duševne vsebine in ta vsebina je merodajna pri sodbi, katera glasba je lepa in katera ni. Glasba je govor, ki sicer ne deluje s tako gotovimi in določnimi pojmi, ki pa slika čustva tako globoko in razpoloženje (občutje) tako neposredno kot nobena druga umetnost."?

Tudi v tem semestru se Dolinar spet ni odločil za Lachova predavanja (Musik und Vogelgesang, 2 uri; Methoden und Probleme der vergleichenden Musikwissenschaft, 2 uri; Entwicklungsgeschichte des europäischen Gesellschaftstanzes, 1 ura) in za predavanja W. Fischerja (Geschichte der Instrumentalmusik II, 4 ure; Die Mensuralnotation des 15. und 16. Jahrh. (Forts.), 2 uri; Übungen zur Geschichte der Instrumentalmusik, 2 uri). Prav tako pa ni vpisal predavanj E. Wellesza (Die Musik im 2o. Jahrhundert, 1 ura) in M. Dietza (Die geschichtliche Entwicklung der Sinfonie und verwandter instrumentaler Kunstformen (mit vielen Musikbeispielen), 3 ure).

$\mathrm{V}$ tem semestru je torej Dolinar izbral na muzikološkem oddelku le dva predavatelja, Adlerja in Orla; pri obeh pa vse cikle predavanj, ki sta ju razpisala. Iz seznama izbranih predavanj je tudi razbrati, da Dolinarja izrazito niso zanimale etnomuzikološke in podobne "primerjalne« muzikološke discipline.

V zimskem semestru 1923-24 je Dolinar izbral le eno od treh ponujenih Adlerjevih predavanj (znova Übungen im musikhistorischen Institut, 2 uri; zato pa tokrat ne Erklären und Bestimmen von Kunstwerken, 2 uri, prav tako tudi ne Stilperioden der Musikgeschichte, 1 ura). Znova je poslušal tudi Lachovo glasbeno estetiko (Die Hauptprobleme der Musikästhetik, 2 uri), pa spet ne dveh drugih njegovih predavanj (Entwicklung der musikalischen Instrumente und Instrumentation, 2 uri; Ibsens »Peer Gynt « und Griegs Musik, 1 ura). Poleg tega je izbral prvič predavanje o notaciji (W. Fischer: Die Mensuralnotation d. 15. und 16. Jahrhunderts, 4 ure) ter prvič kot predavatelja Egona Wellesza (1885-1974) s ciklom predavanj o opernih začetkih (Die Anfänge der Oper, 1 ura).

Med zunanjimi predavatelji je izbral Uvod v etiko (Einführungen die Ethik, 3 ure) enega vodilnih predstavnikov dunajskega logičnega empirizma, Friedricha Alberta Moritza Schlicka (1882-1936) ter predavanje Han- 
sa Uebersbergerja o ruski državi in družbi (Staat. Gesellschaft in Rußland, 3 ure), ki ga je leto pozneje poslušal še en slovenski študent, Bratko Kreft. ${ }^{10}$

Zanimivo je, da v zimskem semestru 1923-24 Dolinar ni vzel niti enega od treh razpisanih Orlovih predavanj (Das rhythmische Problem in der Entwicklung der Notation, 1 ura, Übungen an Werken der Wiener Moderne, 2 uri; Die mehrstimmige Musik des späteren Mittelalter, 1 ura). Prav tako je nekoliko zanemaril izrazitejše muzikološke predmete - poleg navedenih še Dietzova predavanja o glasbeni romantiki (Anbruch und Blüte der musikalischen Romantik (mit vielen Musikbeispielen), 3 ure), Fischerjevo o Bachu (4 ure) ter Haasovo predavanje o zgodovini opere v 18. stoletju (Geschichte der Oper im 18. Jahrhundert, 2 uri). Vse to se umakne Dolinarjevemu očitnemu zanimanju za teme, ki načenjajo splošna družbena vprašanja, Slovanstvo ipd.

Omenjeno tendenco je zaznati tudi v naslednjem, letnem semestru 1924. Adlerjeva temeljna predmeta (Übungen im musik-hist. Institut, 2 1/2 ure; in Erklären und Bestimmen von Kunstwerken, $2 \frac{1}{2} 2$ ure) je Dolinar dopolnil z Lachovimi predavanji o razvoju sodobnega orkestra in instrumentacije po 17. stoletju (Entwicklungdes modernen Orchesters und der Instrumentation seit dem XVII. Jhdt., 2 uri) ter očitno bolj filozofsko naravnanim predavanjem iz glasbene estetike (Die Hauptprobleme der Musikästhetik II: Form und Inhalt, 2 uri) ter filozofije glasbene zgodovine (Philosophie der Musikgeschichte, 1 ura). Poleg tega je poslušal še nadaljevanje Fischerjevih predavanj o menzuralni notaciji (Die Mensuralnotation der 15. und 16. Jahrh. (Forts.), 4 ure) ter predavanje o zgodnjem razvoju opere (Vorstufen der Operngeschichte, 2 uri) Roberta Haasa (1886-1960).

Spet si je zunaj muzikološkega oddelka izbral predavanja H. Uebersbergerja o državni cerkvi in sektah v Rusiji (Die Staatskirche und Sekten in Rußland, 2 uri) ter Rüblerjev uvodni kurs iz psihologije (Einführungskurs in die Psych., 2 uri).

Tokrat se Dolinar znova ni odločil za nobenega od Orlovih predavanj (Die Musik der Troubadours und Minnesänger, 1 ura; Das Vorspiel zu R. Wagners "Tristan und Isolde«, 2 uri; Die mehrstimmige Musik des späteren Mittelalters »«, 1 ura), pa tudi ne za Welleszovo predstavitev opere v 17. stoletju (Die Oper im 17. Jahrh., 1 ura), Fischerjeva predavanja o Bachu (4 ure) in Dietzovo analizo nove romantike (Die Neuromantik in der

10 Tone Smolej, "Kaj večega poskusiti in postati«. Slovenski pisatelji dunajski študentje (1850-1926) (Ljubljana: Založba ZRC/Znanstvena založba Filozofske fakultete, 2015), 143. 
Tonkunst hohen Stils, ihre Ideale und ihre Führer (mit vielen Musikbeispielen), 3 ure)

Za postopno spremembo težišča njegovega širšega strokovnega interesa, kot se kaže v razpisanih predavanjih, je torej značilno, da se je Dolinar vse bolj usmerjal v vprašanja ruske oz. splošne slovanske kulturne zgodovine, poleg tega pa se je znova posvetil obči psihologiji.

$\mathrm{S}$ šestim absolviranim semestrom se je Dolinarjev redni študij na dunajski univerzi končal. Dolinar je sicer svoj dunajski študij videl tudi v smislu širšega konteksta celovitega življenjskega in predvsem glasbenega izpopolnjevanja. Zanimivo, čeprav posredno, je to moč zaznati iz njegovega prispevka ob 6o-letnici Josipa Čerina, še enega dunajskega študenta pri Adlerju. Lahko domnevamo, da opis Čerinovega dunajskega študija pravzaprav posredno razkriva lasten Dolinarjev pogled na to:

»Po dovršenem konservatoriju se je [Čerin] vpisal na filozofsko fakulteto dunajske univerze in dosegel doktorat iz glasboslovja, da je bil tehnično in estetsko kar najbolj pripravljen; poleg tega je pa živel na Dunaju bil v stalnem stiku s svetovnim glasbenim tokom, da je bila tako vsaka enostranost izključena. " ${ }^{\text {II }}$

Lahko bi torej rekli, da je študij, ki ga je pozneje prav tako kot Čerin zaključil z doktoratom, Dolinarju pomenil »tehnično in estetsko izpopolnitev«, samo bivanje na Dunaju pa mu je omogočilo najbolj širok vpogled v sodobna glasbena snovanja. Svoja spoznanja in doživetja bogatega dogajanja $\mathrm{v}$ tej glasbeni prestolnici je delil tudi s slovenskimi bralci in tako poročal o dunajskem glasbenem življenju v Cerkveni glasbenik (s. 8). Njegovi zapisi kažejo, kako si je prizadeval, da bi poleg študijskega izpopolnjevanja izkoristil možnosti, ki mu jih je Dunaj s svojim bogatim koncertnim in širšim kulturnim utripom ponujal.

Ob koncu študija, ko naj bi Dolinar nastopil mesto učitelja glasbe v šentviški gimnaziji, zaradi česar so ga predstojniki poslali na Dunaj, pa se je Dolinar pedagoškemu delu odrekel. „Kot vemo, je pa Dolinar, ko je že skoraj končal študije na Dunaju, izjavil, da nima veselja za pedagoško delo v zavodu, kar je bil vsekakor hud udarec za vse odločujoče, ki so nanj računali, « ${ }^{\mathrm{I}}$ se tega spominja $M$. Tomc, ki ga je škof Jeglič pozneje izbral za 
predvidenega učitelja glasbe $\mathrm{v}$ šentviški gimnaziji ter ga s tem namenom podobno kot Dolinarja poslal študirat na Dunaj. ${ }^{13}$

Po zaključenem rednem študiju leta 1924 je tako škof Dolinarja poklical nazaj v domovino v dušno pastirstvo in mu naložil kaplansko delo najbrže še nekoliko nejevoljen nad njegovo odločitvijo - bolj na obrobju škofije. Znova o tem plastično pripoveduje Tomc: „Vemo pa, da se je to [namreč odklonitev gimnazijske profesure] Dolinarju otepalo! Poslali so ga na razne kraje za kaplana, celo v Stari trg ob Kolpi (ki je, rekel bi, kar Bogu za hrbtom. Jaz kot Belokranjec nisem bil še nikoli tam, je res preveč od rok). Tako je Dolinar promoviral šele takrat, ko sem bil že jaz na Dunaju. ${ }^{14}$

Dolinar je tako kot kaplan služboval v Starem Trgu na Kolpi, pozneje pa še v Borovnici, Tržiču, na Jesenicah in pri svetem Jakobu v Ljubljani.

Za dokončanje študija je škof nato leta 1926 odobril Dolinarju 3 mesece dopusta, leta 1927 pa nato še 2 meseca za dokončanje disertacije. Junija 1927 je tako obranil pod Adlerjevim mentorstvom doktorsko disertacijo z naslovom Die Behandlung der Kirchentöne bei Palestrina.

\section{Vpliv Adlerja na Dolinarjevo glasbeno-zgodovinsko delo}

Leta 1926, torej še pred oddajo in obrambo svoje disertacije, je Dolinar objavil oceno tedaj slovitega zgodovinskega pregleda $\mathrm{z}$ naslovom Handbuch der Musikgeschichte. Z njim je Adler kot urednik povezal 32 strokovnjakov za posamezna področja, nato pa delo vsebinsko in slogovno poenotil. Med številnimi sodelavci razumljivo najdemo številne Adlerjeve dunajske kolege, ki jih je v času svojega študija spoznal seveda tudi Dolinar, saj gre za delo, ki je nastajalo prav v času Dolinarjevega študija na Dunaju (Adler predgovor k prvi izdaji opremi z datumom »april 1924«).

Razumljivo je, da je Adlerjeva glasbeno-zgodovinska šola močno zaznamovala tudi Dolinarjevo mišljenje. In morda prav ta zapis posredno jasno kaže, kako se je v svojem razumevanju zgodovinskega razvoja Dolinar neposredno opiral na Adlerjeva spoznanja. Glasbeni zgodovinar naj išče notranje vezi med posameznimi dogodki v času:

"Ne mislim podrobno govoriti o tem delu, poudariti hočem le nekaj dejstev. Kdor se je za tovrstna vprašanja zanimal, je ravno pri

13 Zanimivo je, da je pozneje Dolinarjeva sestra, Lojzka Dolinar, gospodinjila pri istem Matiji Tomcu, ko je župnikoval v Domžalah, kot je razvidno iz ohranjenih Dolinarjevih dokumentov v mapi Kronika v Glasbeni zbirki Narodne in univerzitetne knjižnice v Ljubljani. 
izbiri primerne knjige prišel vedno $v$ zadrego, vse knjige so se le bolj omejevale $v$ naštevanju zunanjih okolnosti (življenjska data skladateljev, naštevanje njihovih del i. t. d.), toda da bi se iskale one notranje sile, ki so tičale na dnu raznim kulturnim dobam in jim dajale svoj poseben značaj, da bi motrile, kako so se iste časovne ideje različno oblikovale $v$ vseh raznih umetnostnih panogah - take glasbeno-zgodovinske je manjkalo. " ${ }^{\text {15 }}$

Temeljna naloga glasbenega zgodovinarja torej ni naštevanje zgodovinskih dejstev, ampak iskanje njihove notranje povezave, razbiranje povezovalnih sil med različnimi umetnostmi, saj izražajo istega duha, so odraz istih »časovnih idej«.

V zapisu ob stoletnici Beethovnove smrti v Pevcu istega leta 1926 to Dolinar zgoščeno izrazi:

"Če bi hoteli dosedanji zgodovinski razvoj glasbene umetnosti po glavnih osebnostih na kratko označiti, bi poudarili imena: Gregor Veliki, Palestrina, Beethoven, Wagner. [...] Razvoj vsaktere umetniške osebnosti je odvisen najprej od časovnih razmer, $v$ katerih dotičnik dozoreva, in potem od bolj ali manj izrazite umetniške individualnosti. Ta dva činitelja se dasta $v$ življenju vsakogar jasno ločiti in njuno spoznanje je najboljši ključ za razumevanje celotnega umetniškega stvarjanja, kot tudi posameznih večjih del. ${ }^{16}$

Podobno lahko beremo pri G. Adlerju:

"Nebst der Erörterung das eigentlich musikalischen Entwicklungsganges ist entsprechend den Erfordernissen höherer Stilkritik auch das kulturhistorische Moment und die Biographistik berücksichtigt, die Abhängigkeit und der Zusammenhang der Tonkunst und ihrer Meister von und mit den Geistes- und Gefühlsströmungen der betreffenden Zeiten. « ${ }^{17}$

G. Adler se je izčrpneje posvečal vprašanjem slogovnega soodvisnosti med umetnostmi in izdelal koncept znanosti, ki je temeljil na teh premisah, tudi v drugih razpravah, ki so nastajale v času Dolinarjevega študija pri njem, med katerimi poleg Handbuch der Musikgeschichte izstopata vsaj Der Stil in der Musik in Die Methode der Musikgeschichte. Obe deli v

15 Anton Dolinar, »Handbuch der Musikgeschichte«, Pevec 6, 5-6 (1926): 34-35.

16 Anton Dolinar, »Ob stoletnici Beethovnove smrti«, Pevec 6, 3-4 (1926): 9.

17 Guido Adler, ur., Handbuch der Musikgeschichte (Tutzing: Hans Schneider, 1961), V. 
izdajah Breitkopfa in Härtla iz leta 1911 Dolinar med viri tudi navaja v svoji disertaciji.

Dolinar kot enega prvih muzikologov, ki so glasbeno zgodovinopisje zaznamovali s tako usmerjenim pogledom, v omenjeni oceni Adlerjevega dela navaja Huga Riemanna (1849-1919), leipziškega učitelja prvega muzikološkega doktoranda s Kranjske, Antona Krisperja (1858-1914). Kot poudarja Dolinar, je bil Riemann začetnik glasbenozgodovinskega univerzitetnega študija: »in treba je bilo prav veliko podrobnega dela, da so se mogli pokazati prvi sadovi in uspehi «. ${ }^{18}$

Dolinar je v omenjeni oceni Adlerjeve zgodovine menil, da se je po Riemannu pokazalo, kako nujno je povezovalno delo različnih strokovnjakov. Celotna zgodovina predstavlja namreč preprosto preobsežno snov za enega samega raziskovalca, zato je pozdravil Adlerjev uredniški projekt.

Zanimivo pri tem je, da je bil Dolinar v svoji oceni Adlerjeve zgodovine vendarle tudi kritičen; in sicer do dejstva, da v njej niso omenjeni Južni Slovani:

»K razpravi o novejši (moderni) glasbi so pritegnjeni vsi evropski narodi (izmed Slovanov Rusi, Poljaki, Čehoslovaki). Le o glasbi južnih Slovanov knjiga molči, kar celotni knjigi škoduje. Upajmo, da se to popravi v drugi izdaji." ${ }^{19}$

Očitno se je Adler zavedal utemeljenosti navedene kritike - in prav mogoče bi bilo, da bi mu jo neposredno izrazil tudi Dolinar sam, denimo $\mathrm{v}$ času priprave na zagovor disertacije. Adler se je vsekakor pozneje odločil zgodovinski pregled razširiti in dopolniti. Tako je v predgovoru k drugi izdaji zapisal:

"Dem mehrfach geäußerten Wunsch nach Teilung in 2 Bände wurde entsprochen - zumal da einige Abschnitte neu eingefügt, andere ergänzt wurden. ${ }^{20}$

Kot da bi prisluhnil Dolinarjevi kritiki, je Adler v drugo izdajo zbornika nanovo vključil tudi poglavje o južnoslovanski glasbi, ki ga je prispeval Adlerjev dober znanec iz njegovih dunajskih let, še en Kranjec, Josip Mantuani.

18 Dolinar, »Handbuch der Musikgeschichte«, 34.

19 Prav tam, 35.

20 Adler, Handbuch der Musikgeschichte, VII. 
Kako je Dolinar tudi pozneje sledil Adlerjevim glasbenozgodovinopisnim nazorom, kaže vrsta njegovih zapisov tudi iz poznejših let. Med njimi izstopa nekoliko obsežnejša razprava »Iz glasbenega razvoja, « ki jo je objavil v Cerkvenem glasbeniku leta $1932 .{ }^{21}$ Besedilo znova odpre programatski zapis:

"V celotnem zgodovinskem dogajanju vidimo dejstva največjega pomena, ki zaključujejo večstoletne razvojne dobe in hkrati tvorijo osnove enako dolgim razdobjem; vmes med temi najdemo zopet manjše dogodke, ki se razvijejo v okviru teh večjih in pomembnejših dogodkov, ki so v svoji vrsti tudi enako važni in tehtni, vendar manjše časovne dobe obsegajoči. [...] Taka silna razdobja bi mogli primerjati onim silnim morskim valovom, ki se pojavijo le v najvišjem viharnem razburkanju, ki se pa dele in nosijo s seboj toliko in toliko manjših valov. Vsi ti silnejši in manjši dogodki vtisnejo pečat tudi vsemu duhovnemu življenju, ki vsa ona gibanja silhuetno na sebi očituje. [...] Najsibo umetnina še tako v osebni ustvarljiteljevi noti zasidrana, bo vkljub temu nosila duševni pečat dobe, iz katere izvira: $k$ vsemu temu pa pridejo še nehote vpoštev posebne značilnosti posameznih narodnosti - in to brez ozira na katerokoli dobo - da Npr. ni vseeno, ali je delo nastalo v Rimu ali Antwerpnu - seveda istočasno mišljeno. ${ }^{22}$

Poleg tega najdemo tudi za ta čas značilno poudarjanje antagonizma med obliko in vsebino, ki ga Dolinar neposredno ponazori kar z Adlerjevim citatom:

"Zunanja oblika pa tako $v$ arhitekturi kot tudi $v$ glasbi le tedaj nekam oživi in se kot umetnost prikazuje, če se kot nujen estetski zakon kar vtelesi in $v$ tem estetskem zakonu umetnik svojo vizijo tako rekoč pred seboj doživlja."«3

Za splošno poznavanje izsledkov Dolinarjeve disertacije pa je seveda ključnega pomena objava članka, ki je v nadaljevanju izhajal v Cerkvenem glasbeniku leta 1930. Prispevek z naslovom »Iz uvoda k razpravi: Cerkveni toni v večglasju« Dolinar sam predstavi kot slovensko reproduciranje uvo-

21 Anton Dolinar, »Iz glasbenega razvoja«, Cerkveni glasbenik 55 (1932): 14-17, 50-53, $113-115$.

22 Prav tam, 14.

23 Adler, Handbuch der Musikgeschichte, 694; cit. po: Dolinar, "Iz glasbenega razvoja," 15 . 
da k svoji disertaciji z uvodno pripombo: »Oficialni naslov se glasi: Die mehrstimmige Behandlung der Kirchtöne bei Palestrina. ${ }^{24}$

V Dolinarjevi razpravi se splošna obravnava glasbene preteklosti prepleta $\mathrm{z}$ glasbeno estetiko, ta pa s filozofijo zgodovine. Vse to smo lahko zaslutili ne nazadnje tudi iz izbora vpisanih predavanj na dunajski univerzi. Čeprav gre torej za značilno zgodovinsko temo, jo avtor osvetljuje v luči sodobnih glasbeno-estetskih poudarkov.

Tako tudi stare cerkvene tonovske načine kot osrednji predmet svojega preučevanja razume in razlaga $\mathrm{v}$ kontekstu glasbe svojega časa.

V osnovi se Dolinar osredotoča na tonovske načine in njihovo mesto zlasti v kontekstu prehoda iz 16. v 17. stoletje:

„Če bi celotni tonski sistem primerjali solnčnemu žarišču, bi mogli cerkvene tone -, ki so iz tega žarišča izhajali in $v$ njem svojo eksistenčno upravičenost dobivali - prispodabljati žarkom iz tega centra se porajajočim: in ravno za te (cerkvene tone) pomeni čas okrog l. 16oo. naravnost dobo za obstanek, prav za prav neke vrste revolucionarno dobo. Omenjeni cerkveni toni, ki so bili $v$ rabi $v$ dobi vokalne polifonije, tvorijo $v$ celotnem razvoju oblikovnega muzikalnega materiala važen člen in ta razvoj sega daleč nazaj. Neposredno se naslanjajo nazaj na tonovske načine koralnega enoglasja; ti so pa zopet po imenu in tudi stvarno $v$ sorodu $z$ antičnimi tonskimi sistemi, katere sta pa grški in pozneje latinski srednji vek tako preoblikovala, da so dobili v koralu novo, njegovemu bistvu primerno izklesanost in uravnanost. ${ }^{25}$

Zgodovinski pogled pa obrne na sočasne razmere:

"In isti boj, ki je bil začetkom 17. stoletja napovedan sistemu cerkvenih tonov, velja že nekaj desetletij sem obema: duru in molu. Za dobo raznih-izmov (impresionizma, ekspresionizma, futurizma) se zdita oba - dur in mol - prešibka, da bi mogla povsem zadovoljiti vsej skali notranjega občutenja novodobnega človeka. In stalno so vedno bolj pogostni glasovi, ki podirajo temelje durmolski heptatoniki in napovedujejo celotonski, četrttonski, atonalni itd. sistem:

24 Anton Dolinar, »Iz uvoda k razpravi: Cerkveni toni v večglasju«, Cerkveni glasbenik 53 (1930): 1-3, 33-35, 65-68, 97-100, 129-133, 169-172. 
isti razvojni proces se $v$ živem organizmu glasbene umetnosti javlja in ponavlja vedno znova. ${ }^{26}$

Dolinar predstavi tudi ključen problem disertacije, ki je v razumevanju preobrazbe cerkvenih tonovskih načinov pri njihovi rabi v obdobju vokalne polifonije ter nato njihovo preoblikovanje v dur-molovsko tonaliteto.

Kot glavno avtoriteto na področju korala izpostavlja Dolinar v svoji disertaciji zlasti Petra Wagnerja, ki ga k svoji zgodovini pritegne tudi Alder. Poleg tega izpostavlja še Petra Mortimerja, A. Oberländerja in Jurija Arnolda (1811-1898) - zlasti slednji je bil za Dolinarja razumljivo posebno zanimiv kot ruski muzikolog, ki se je s svojim pisanjem, odmevnim tudi na zahodu, ukvarjal obsežno $\mathrm{z}$ vplivom cerkvenih tonovskih načinov na rusko cerkveno glasbo.

Prav tako Dolinar pogosto vpleta navedke Weinmanna, pa tudi nekaterih svojih učiteljev - poleg Adlerja zlasti Alfreda Orla.

Dolinar v članku navaja za slovensko bralstvo zanimivo in v veliki meri bržkone manj znano muzikološko literaturo in izpostavlja ključne publikacije s tega področja, tudi Adlerjeve, ki jim v okviru izvirne disertacije sicer razumljivo ne namenja tako izrazito poudarjenega prostora in širše razlage. Prav tako za slovensko bralstvo nekoliko razširi odlomek, $\mathrm{v}$ katerem splošen prikaz razvoja cecilijanskega gibanja dopolni z vpogledom v slovenske razmere. Dejansko se Dolinar cecilijanskemu gibanju in njegovi zgodovini v slovenski verziji teksta daleč izčrpneje posveti kot $\mathrm{v}$ nemškem izvirniku, kar kaže na to, kako je svoje besedilo v nadaljevanju vse bolj izrazito oblikoval po meri slovenskega bralca, tudi če se je tako povsem oddaljil od nemške predloge. Zdi se, kot da bi se s tem Dolinar delno poklonil okviru svoje objave znotraj Cerkvenega glasbenika kot publikacije slovenskega Cecilijinega društva, posredno pa je morda tudi reagiral na razpravo $\mathrm{z}$ naslovom »Zgodovina cerkvene glasbe« J. Mantuanija, ki ga je uredništvo Cerkvenega glasbenika objavljalo v nadaljevanjih vzporedno $\mathrm{z}$ Dolinarjevim besedilom, sam Dolinar pa ga je po Mantuanijevi smrti $z$ naslovom »Zgodovina katoliške cerkvene glasbe « tudi nadaljeval. Pozneje je razprava izšla tudi v obliki separata. ${ }^{27}$

V slovenski verziji Dolinar tudi ni označil nekaterih virov svojih navedkov (tako že takoj na začetku citat P. Wagnerja). Poleg tega se je nekoliko nerodno v slovenskem prevodu celo skliceval na nadaljevanje svo-

26 Prav tam, 2.

27 Josip Mantuani in Anton Dolinar, Zgodovina katoliške cerkvene glasbe (Ljubljana: Cecilijino društvo, 1938). 
je disertacije (dobesedno denimo: $॥$ v drugem delu razprave motrimo ... $\aleph^{28}$ ). Tovrstno opozorilo, ki je v izvirniku razumljivo, saj gre za napotek na besedilo, ki sledi predstavljenemu uvodu, v slovenski skrajšani verziji z zgolj uvodnim poglavjem disertacije seveda nima pravega smisla.

Vsaj na začetku skrbno zastavljen prevod uvoda $\mathrm{v}$ disertacijo se $\mathrm{v}$ nadaljevanju oddaljuje od svojega izvirnika in postaja samostojna razprava, namenjena širšemu slovenskemu bralstvu in konkretnemu zgodovinskemu trenutku.

Avtor se tudi sicer že v samem uvodu v disertacijo oddaljuje od glavne tematike, začrtane $\mathrm{v}$ njenem naslovu. Poleg omenjene obravnave cecilijanizma se tako posveti tudi vprašanju »cerkvenosti« glasbe. Prav tako razpravo zasnuje $\mathrm{z}$ mislijo na konkretne sodobne glasbeno-estetske dileme. Tako se ob koncu objavljene razprave znova vrne $\mathrm{k}$ izhodiščnim tezam in poudarja, kako sodobna glasba oživlja nekatere vidike, ki jih nakazuje »klasična a cappela glasba «" ${ }^{29}$, kot to imenuje Dolinar: sproščen ritem, ki se oddaljuje od »tiranije enakomernega taktovega ritma « ${ }^{30}$, in zavračanje dur-molovske tonalitete, kar da v sodobni glasbi »kaže, da se vračamo zopet na posodo $\mathrm{k}$ starim cerkvenim tonovim načinom, ko npr. med posameznimi lestvicami ni bilo posebnih bistvenih ločitvenih znakov. ${ }^{31} \mathrm{Ne}$ glede na vprašanje utemeljenosti njegovih postavk pa je soočanje zgodovinske teme s premislekom in estetskim utemeljevanjem sočasne stvarnosti seveda še danes zanimivo.

Dolinar se je očitno že kot študent muzikologije navduševal nad temi idejami, kot lahko razberemo tudi iz poročila o dunajski koncertni sezoni, objavljenega leta $1924 \mathrm{v}$ Slovencu. V izpostavljanju ruskih glasbenih del in navduševanju zanje celo med dunajsko publiko, ki je bila sicer zlasti po koncu svetovne vojne zadržana do nenemške ustvarjalnosti, vidi jasno izražen estetski normativ svojega časa, po katerem se je prelom dur-molovskih okvirov dopolnjeval z iskanjem »neomadeževanih« tradicij:

"Razmeroma zelo veliko je bilo slišati letos ruskih glasbenih del. Splošno dejstvo je, da zanimanje ravno za te proizvode zelo raste in da se vedno povdarja, da je tam še polno nedvignjenih zakladom zakopanih, ki bi bili zmožni doprinesti celotnemu toku prav mnogo novih razvojnih možnosti. [...] Poznejša dur in mol sta te sledo- 
ve popolnoma izbirsala, kar nikakor ne moremo kot posben [sic!] napredek beležiti, če pomislimo, da je cilj današnjega časa zopet na tem, da se izmota iz tega omejenega naročja, in nehote prihajajo stari tonovi načini zopet do veljave - pri katerih sta dur in mol tudi že obstojala (jonski aeolski tonov način), toda nista bila izključno merodajna in se je poleg teh obeh nahajalo še več vmesnih stopenj (frigični tonov način) med obema sklajnima poloma. Ta proces ločitve $v$ dur in mol se je izvršil koncem 17. stoletja, toda največji povdarek je dobil potem $v$ 18. stol. pri dunajskih klasikih, osobito pri Beethovnu. Vse kulture, ki so bile kolikor toliko v zvezi oziroma bolj ali manj odvisni od nemške, so to ločitev sprejele in če ruska kultura temu ni popolnoma podlegla, je iskati vzroka le $v$ veliki oddaljenosti od srednjeevropskega ozemlja. «2

Kot lahko pokaže analiza Dolinarjeve disertacije, ki jo kot tipkopis hrani danes knjižnica dunajske univerze, ${ }^{33}$ je premislek, ki je temeljil na povezovanju preteklih glasbenih sistemov s sodobnimi kompozicijskimi in estetskimi načeli, vendarle lahko vodil tudi v nekatere problematične metodološke principe in s tem povezane sklepe. $\mathrm{V}$ tem smislu izstopa analiziranje renesančne vokalne polifonije s pomočjo analitične optike, razvite ob dur-molovski funkcijski harmoniji. Prav to namreč tvori pomemben del Dolinarjeve disertacije, osredotočene na prelom v funkcijsko dur-molovsko harmonijo, ki naj bi se uresničil v času Palestrine.

Brez dvoma so občudovanja vredne Dolinarjeve obsežne in natančne statistične obdelave Palestrinovega opusa, pri čemer avtor disertacije precizno določa najrazličnejše parametre glasbe, ki jih uredi v številne pregledne tabele. Tako lahko $v$ tekstu sledimo denimo skrbnemu popisu cerkvenih tonovskih načinov, kot se pojavljajo $\mathrm{v}$ različnih zvrsteh in posameznih zbirkah. Avtor tudi ponazori, kakšen ambitus ima v skladbah vsak posamezni glas in kakšen interval ti glasovi obsegajo. V nadaljevanju opiše značilnosti melodije $\mathrm{v}$ primerjavi s koralnimi načini tvorjenja melodije in obravnava tipe melizmov. Pogleda in našteje tudi različne modele začetkov in sklepov skladb ter jih celo označi s pomočjo funkcijske teorije. Funkcijski analizi podvrže tudi analizo širših harmonskih zvez v posameznih skladbah. Sicer je pri tem v osnovi nekoliko zadržan in opozarja, da so

32 Anton Dolinar, "Nekaj zanimivosti dunajske koncertne sezone. Slovanska glasba«, Slovenec 52 (1924), 152 (6. 7.): 6.

33 Anton Dolinar, Die mehrstimmige Behandlung der Kirchtöne bei Palestrina (doktorska disertacija, Universität Wien, 1927). 
akordske tvorbe pogosto naključen rezultat vodenja linij (»es werden zwar Akkorde gebildet, jedoch diese Bildung ist nur ein zufälliges Resultat geführter Einzelstimmen ${ }^{34}$ ). Pa vendar v nadaljevanju iz tega izpelje sklepe, v kolikšni meri pride tudi pri Palestrini do osnovnih harmonskih tonalnih funkcij: »Selbstverständlich werden wir nachsuchen, ob und wie grossem Masse die Funktionen der Tonika, Dominante, Subdominante auch in der palestrinänsischen Mehrstimmigkeit zur Geltung kommen, und wie ihre Äusserung dort Platz ergreift..135 $\mathrm{V}$ tej zvezi govori celo o modulacijah, sredstvih za moduliranje, kadenčnih zvezah ipd.

Tako pride ob sklepu disertacije do ključnih treh sklepnih vprašanj (resultierende Fragen):

1. Značilnosti tonskih načinov« (Die Charakteristik der Tonarten)

2. $» N a$ kateri stopnji pride pri Palestrini do preloma s cerkvenimi tonovskimi načini ter njihove izostritve v dur in mol?« (In welchem Stadium befindet sich bei Palestrina der Durchbruch der Kirchentöne und deren Zuspitzung in 1 Dur in 1 Moll?)

3. „Razlike pri obravnavi posameznih cerkvenih tonovskih načinov« (Die Verschiedenheiten in der Behandlung einzelner Kirchentöne)

V disertaciji se torej Dolinar kaže kot izjemno natančen, skrben in sistematičen analitik, ki pa vendar zaradi danes nekoliko spornih metodoloških konceptov privede bralca do nekoliko problematičnih sklepov.

V svoji oceni disertacije $\mathrm{z}$ dne 24 . junija 1927, ki jo danes hrani dunajski univerzitetni arhiv, je bil nekoliko zadržan tudi G. Adler. Sicer je pohvalil marljivo Dolinarjevo delo, a je bil do njega tudi kritičen: »Disertacija je bleščeče izdelana, vendar pravzaprav ni pripeljana do konca." (Die Dissertation ist glanzig gearbeitet, aber eigentlich nicht zum Abschluss gebracht.) Adler je izpostavil »koristno" rabo statistike (Das Hilfsmittel der Statistik braucht er mit Vorteil) in harmonsko analizo. Kritičen pa je bil izrazito do rabe dolgih citatov, ki so po njem pogosto v nasprotju z Dolinarjevimi lastnimi stališči. Prav tako je opozoril na nejasno delitev med »modulacijo" (Modulation) in »izmikom« (Ausweichung). Opozoril je tudi na »zastarelo literaturo" (überholte Literatur) ter jezikovne pomanjkljivosti, pri čemer je izpostavil dejstvo, da je avtor disertacije Slovenec. Tako je v sklepu zapisal: »Delo potrebuje za morebitno objavo (brez dvoma vredno) izboljšave in dodatni študij. Vendar tudi na tej stopnji je kot disertacija popolnoma

34 Dolinar, Die mehrstimmige Behandlung, 104.

35 Prav tam, 107. 
zadostna." (Die Arbeit benotigt für eventuelle Veröffentlichung (ruerthens wert) der Stochbesserung und ergänzender Studien. Aber auch in dem gegenwärtigen Stadium ist sie als Dissertation vollgenügend.)

Profesor Robert Lach se je kot koreferent 25. junija 1927 skopo pridružil Adlerjevi oceni.

Žal kljub Adlerjevemu priporočilu do natisa disertacije ni prišlo, samo besedilo pa je bilo močno okrjeno širši javnosti dostopno le prek objave omenjenega slovenskega prevoda in predelave uvodnega poglavja, posredno pa so osrednje teze razprave prosevale še $\mathrm{v}$ nekaterih drugih avtorjevih zapisih zlasti glasbeno-estetskega značaja. Poleg tega bi lahko sklepali, da je seveda svoje ideje Dolinar posredoval javnosti tudi prek številnih drugih javnih nastopov, zlasti v okviru novoustanovljenega Radija Ljubljana, v delo katerega se je aktivneje vključeval.

Po disertaciji se je namreč Dolinar postal vse bolj viden del slovenskega kulturnega življenja. Že kot kaplan v Tržiču, pred zagovorom disertacije, se je udejstvoval na področju cerkvene glasbe in skrbel za vzgojo tudi duhovnikov. Ob duhovniški konferenci leta 1926 je tako pripravil

"referat o pomenu in stalǐ̌ču, ki ga zavzema glasba o cerkveni liturgiji, in o dolžnostih, ki jih ima duhovnik, kot vršilec liturgičnih opravil do nje. $\mathbb{1}^{36}$

Istega leta je Dolinar postal tudi urednik glasbene revije Pevec. Marko Bajuk je o tem v svojem poročilu na Občnem zboru Pevske zveze leta 1926 zapisal: »Letos je prevzel uredništvo prvotno predsednik Dolinar. Ker pa nam ga usoda ni hotela dati v Ljubljano, sem moral prevzeti odgovorno uredništvo sam. Delila sva si delo tako, da je urejal on priloge, jaz pa list..137 Z Markom Bajukom sta urejala tudi pesmarice Pevske zveze.

$\mathrm{V}$ istem obdobju je postal Dolinar predsednik Pevske zveze ter v tem okviru pripravil nekaj predavanj z glasbeno-estetsko tematiko, s katero se je intenzivneje ukvarjal tudi $\mathrm{v}$ času dunajskega študija muzikologije. $\mathrm{Na}$ podlagi predavanj, ki jih je imel Dolinar na tečajih Pevske zveze leta 1926, je nastal razmeroma obsežnejši članek v $P e v c u^{38}, \mathrm{ki}$ ob še nekaterih drugih zapisih $^{39}$ estetskega značaja po svoji tehtnosti nedvomno izstopa.

36 Anton Dolinar, »Tržič«, Cerkveni glasbenik 49 (1926): 22.

37 Marko Bajuk, »Občni zbor Pevske zveze«, Pevec 6, 9-10 (1926): 51-52.

38 Anton Dolinar, »Donesek h glasbeni estetiki«, Pevec 6 (1926), 37-38, 49-51.

39 Anton Dolinar, »Donesek h glasbeni kritiki«, Cerkveni glasbenik 48, 11-12 (1925): 125-129. 
Poleg tega je nekaj let vodil pevski zbor Ljubljana, kjer je nasledil Franca Kimovca, in bil dirigent Glasbenega društva Ljubljana.

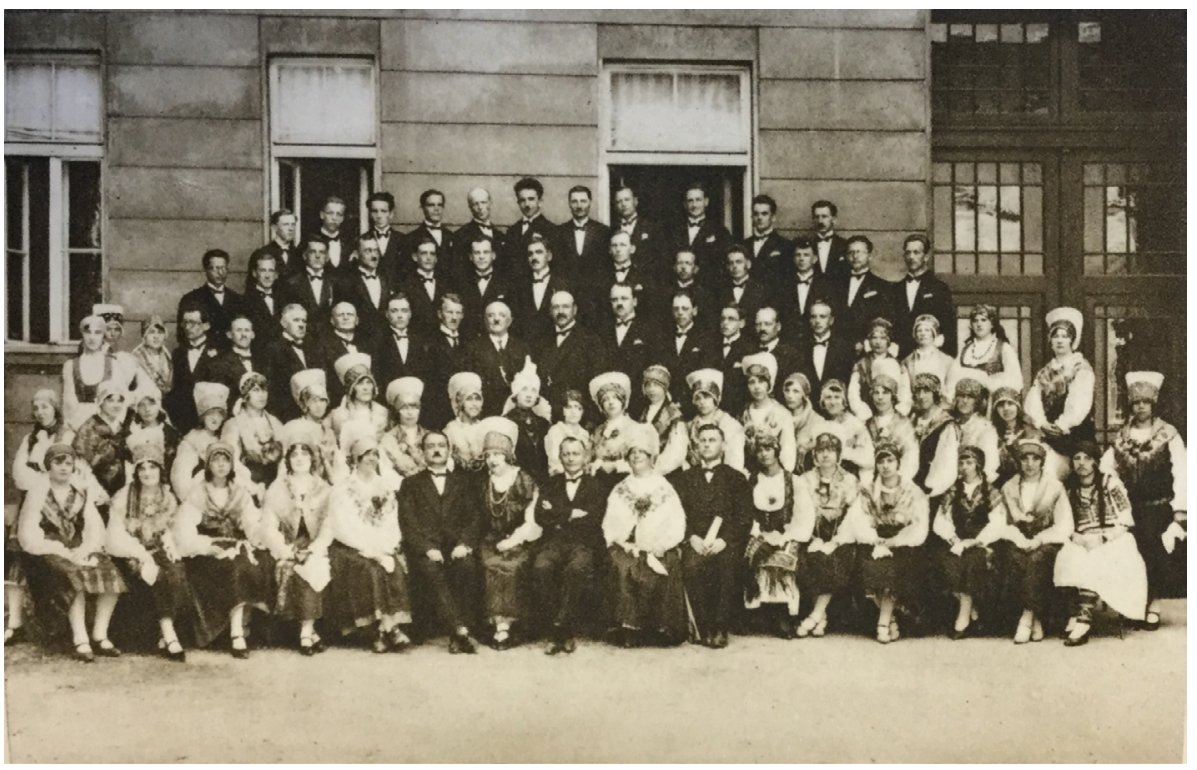

Slika ı: Zbor glasbenega društva Ljubljana z dirigentom Antonom Dolinarjem l. 1929; fotografija je objavljena v dvojezičnem koncertnem listu v slovenščini in češčini, natisnjenem ob gostovanju zbora 1.-10. 7. 1929; mapa Dolinar, Anton, Kronika, Glasbena zbirka NUK, z dovoljenjem.

Dolinar je občasno dirigiral Orkestralnemu društvu Glasbene matice. V njem so igrali študenti konservatorija in poklicni glasbeniki, orkester pa je včasih sodeloval z zbori ljubljanske in mariborske Glasbene matice ter $\mathrm{z}$ zborom Ljubljana (ki ga je vodil Dolinar) in Ljubljanskim zborom. Poleg tega je orkester povprečno enkrat do dvakrat letno snemal za Radio Ljubljana. $^{4 \circ}$

Posebej pomembno pa je bilo nedvomno Dolinarjevo sodelovanje $\mathrm{z}$ Radiom Ljubljana, pri katerem je deloval vse od leta 1928, ko je radijska postaja začela delovati. Bil je urednik oz. referent Radia Ljubljana ter eden najbolj konstantnih radijskih sodelavcev ves čas v obdobju 1928-1945. Ko so leta 1928 so pri Prosvetni zvezi ustanovili radijski odsek, ki je poskrbel za ustanovitev radija, so imenovali tudi širši programski odbor. V njem so so40 Cigoj Krstulović, Zgodovina, spomin, dediščina, 180. 
delovali: Anton Dolinar kot referent za glasbo, referent za prosveto je postal Vinko Zor, referent za propagando Ivan Martelanc. Pozneje, leta 1929, se jim je pridružil še France Koblar kot dramski in kulturni referent, od 1932 pa še Niko Kuret kot referent za šolske in mladinske oddaje. ${ }^{41}$ Leta 1937 so ustanovili pri radijski postaji samostojni komorni zbor, njegov dirigent pa je postal prav Dolinar.

Dolinar se kljub svojemu nasprotnemu stališču po zaključku dunajskega študija vendarle ni povsem odrekel pedagoškemu delu. Tako je nekaj časa deloval tudi kot profesor na ljubljanskem Liceju in na Orglarski šoli.

Po vojni je leta 1945 odšel najprej v Italijo, od tam pa se je nato odselil v ZDA, kjer je živel v zvezni državi Minnesota. Umrl je 1. avgusta 1953 v St. Cloud, ZDA v prometni nesreči v Yates Centru v državi Kansas.

Čeprav je Dolinar bil v svojem času nedvomno eden najbolj razgledanih glasbenih intelektualcev, široko dejaven na najrazličnejših področjih, pri čemer je zlasti izjemno pomembno njegovo dolgoletno zvesto delovanje $\mathrm{v}$ novoustanovljenem ljubljanskem radiu, pa je po vojni kot duhovnik in del politične emigracije postopoma žal njegovo delo po krivici v veliki meri utonilo $\mathrm{v}$ pozabo.

\section{Bibliografija}

Adler, Guido, ur. Handbuch der Musikgeschichte. Tutzing: Hans Schneider, 1961.

Ambrožič, Matjaž. »Profesorski zbor«. V Sto let Zavoda sv. Stanislava. France M. Dolinar, ur.. Ljubljana: Družina, 2005, 439-440.

Auer, Max. Anton Bruckner: sein Leben und Werk. Zürich/Leipzig/Wien: Amalthea 1923.

Bajuk, Marko. »Občni zbor Pevske zveze«. Pevec 6, 9-10 (1926): 51-52.

Brojan, Matevž. Začetki radia na Slovenskem. Ljubljana: Modrijan/Radio Slovenija, 1999.

Cigoj Krstulović, Nataša. Zgodovina, spomin, dediščina: Ljubljanska Glasbena matica do konca druge svetovne vojne. Ljubljana: Založba ZRC, ZRC SAZU, 2015.

Dolinar, Anton. »Anton Bruckner«. Cerkveni glasbenik 47 (1924): 1-4, 27-31, $48-49$.

Dolinar, Anton. »Današnji glasbeni Dunaj«. Cerkveni glasbenik 46 (1923): 102-105.

41 Matevž Brojan, Začetki radia na Slovenskem (Ljubljana: Modrijan / Radio Slovenija, 1999), 22 
Dolinar, Anton. Die mehrstimmige Behandlung der Kirchtöne bei Palestrina, doktorska disertacija, Universität Wien, 1927.

Dolinar, Anton. »Donesek h glasbeni estetiki«. Pevec 6 (1926): 37-38, 49-51.

Dolinar, Anton. »Donesek h glasbeni kritiki«. Cerkveni glasbenik 48, 11-12 (1925): 125-129.

Dolinar, Anton. »Dr. Josip Čerin - 6o letnik«. Pevec 7, 3-4 (1927): 15.

Dolinar, Anton. »Handbuch der Musikgeschichte«. Pevec 6 (1926): 34-35.

Dolinar, Anton. »Iz glasbenega razvoja«. Cerkveni glasbenik 55 (1932): 14-17, 50$53,113-115$.

Dolinar, Anton. »Iz uvoda k razpravi: Cerkveni toni v večglasju«. Cerkveni glasbenik 53 (1930): 1-3, 33-35, 65-68, 97-100, 129-133, 169-172.

Dolinar, Anton. „Nekaj zanimivosti dunajske koncertne sezone. Slovanska glasba«. Slovenec 52 (1924), 152 (6. 7.): 6.

Dolinar, Anton. »'Novi Akordi' (1901-1914)«. Zbori 2, 1-2 (1926): 2-3.

Dolinar, Anton. »Ob stoletnici Beethovnove smrti«. Pevec 7, 3-4 (1927): 9-10.

Dolinar, Anton. »Petletnica PZ«. Pevec 6 (1926): 30-31.

Dolinar, Anton. »Tržič«. Cerkveni glasbenik 49 (1926): 22-23.

Mantuani, Josip in Dolinar, Anton. Zgodovina katoliške cerkvene glasbe. Ljubljana: Cecilijino društvo, 1938.

Sivec, Jože. »Dolinar, Anton«. Enciklopedija Slovenije. 2. zv. Ljubljana: Mladinska knjiga, 1988, 299.

Smolej, Tone. "Kaj večega poskusiti in postati«. Slovenski pisatelji dunajski študentje (1850-1926). Ljubljana: Založba ZRC/Znanstvena založba Filozofske fakultete, 2015.

Snoj, Venceslav. »Prof. V. Hybašek«. V Letno poročilo 1937/1938. Ljubljana: Zavod sv. Stanislava, 10-11.

Premrl, Stanko. »Hybášek, Vojteh (1873-1947)«. V Slovenski bijografski leksikon: 3. zv. Hintner - Kocen. Izidor Cankar, ur., et al. Ljubljana: Zadružna gospodarska banka, 1928, 360 .

Škulj, Edo. »Anton Dolinar (1894-1953): Ob petdesetletnici smrti«. Cerkveni glasbenik 96, 7-8 (2003): 10. žŠkulj, Edo. Letopis slovenskega glasbenega življenja v Argentini: ob 5o. obletnici vélikega izhoda. Celje: Mohorjeva družba; Celovec: Krščanska kulturna zveza; [s. 1.]: Izseljensko društvo Slovenija v svetu, 1995, 42-43.

Škulj, Edo. »Matija Tomc (1899-1986)«. Cerkveni glasbenik 92, 10-12 (1999): $73-80$. 
Škulj, Edo. »Tomčeva pisma«. V Tomčev zbornik. Edo Škulj, ur.. Ljubljana: Družina, 1997, 111-198.

»Dolinar, Anton«. Slovenski bijografski leksikon: 1. zv.: Abraham-Erberg. Izidor Cankar, ur., et al. Ljubljana: Zadružna gospodarska banka, 1925: 141. ${ }^{42}$

42 Poglavje je nastalo kot del projekta J6-7180, ki ga je sofinancirala Agencija za raziskovalno dejavnost Republike Slovenije.

This chapter is part of the project J6-7180 funded by Slovenian research agency ARRS. 